\title{
無電解ニッケル/パラジウム/金めっき皮膜の 鉛フリーはんだ特性
}

\author{
小田幸 典* \\ * 上村工業(㹯) 中央研究所 ( $5573-0065$ 大阪府枚方市出口 1-5-1) \\ Solder Joint Reliability of Lead Free Material \\ for Electroless Nickel/Palladium/Gold Film
}

Yukinori ODA*

*Central Research Laboratory, C. Uyemura \& Co., Ltd. (1-5-1, Deguchi, Hirakata-shi, Osaka 573-0065)

Keywords : Electroless Palladium Plating, Lead Free Solder Material, Solderability, Wire Bondability

\section{1.はじめに}

プリント基板をはじめとした電子部品への機能めっきは部 品の軽量化, 小型化によって, 従来の電気めっき法から無電 解めっき法へと変更されてきている。また，はんだ接合材料 は近年の環境的要求によって, 鉛入りの共晶はんだから, $\mathrm{Sn}-\mathrm{Ag}-\mathrm{Cu}$ などの鉛フリーはんだが主流となっている。

無電解ニッケル / 金めっき皮膜(以降 $\mathrm{Ni} / \mathrm{Au}$ と称す) はこ のように変化する要求を満たすひとつのアイテムではあるが, リフローの多段化など，すべての要求を満たさないケースも ある1)。

また，ICとの接続方法として一般的なものにワイヤーボ ンディングがある。ワイヤーボンディング性が要求される基 板にも無電解化は浸透しつつあり, かつては厚付け置換金 めっき浴を使用した無電解 $\mathrm{Ni} / \mathrm{Au}$ プロセスが多く見られた が，近年では無電解還元厚付け金めっき浴を使用することに より，より高度な要求を満たすことも可能になっている2)。

一方, 数年前からパラジウムめっきも注目されているが, その主たる目的は代用金としてのワイヤーボンディング性で, はんだ接合性に関してはあまり肯定的な結果は得られていな かった ${ }^{2)}$ 。しかし, 前述のように近年の要求変化によりはん だ接合材料の鉛フリー化で, 再びニッケル/パラジウム/金 めっき皮膜(以降 $\mathrm{Ni} / \mathrm{Pd} / \mathrm{Au}$ と称す)が注目されているので 紹介する。

\section{2. パラジウムめっきと午の膜厚}

パラジウムめつき浴はギ酸を還元剤に用いた純パラジウム 皮膜浴 ${ }^{3), 4)}$ と次亜リン酸や覀リン酸を還元剤に用いたパラジ ウムーリン合金皮膜浴がある ${ }^{5), 6)}$ が，従来は純パラジウム浴 を用いる場合がほとんどで, ワイヤーボンディング性は良好 である反面，はんだ接合性は劣るものであった。

そこで, はんだ接合性に重点を置いたパラジウムめっきを
検討したところ，次覀リン酸を還元剤に使用したパラジウム ーリンめつきを用い, 膜厚を従来より薄い $0.06 \mu \mathrm{m}$ 程度にす ることで良好な結果が得られることがわかった。

\section{3. 試料の作成}

テストピースは，銅張り積層板に硫酸銅めつきにて約 20 $\mu \mathrm{m}$ 銅めっき処理した基板と,この基板にソルダーマスクで $0.5 \mathrm{~mm} \phi$ のはんだボールパットを作製したものの 2 種類を 使用した。めつき薬品は上村工業侏製の市販薬品を使用した。 なお，パラジウムめつきについては必要に応じて，パラジウ ムーリン (Pd-P と表記) および純パラジウム (Pure-Pd と表 記) 浴を用いて, 表 1 のとおり膜厚サンプルを作製した。膜 厚はセイコーナノテクノロジー製 SFT-9455 蛍光 X 線膜厚 計を用いて測定した。

\section{4.はんだ接合性試験}

表 1 のとおり作製した皮膜を用い, ボールプルテストを 行った。評価方法を表 2 に, 結果を図 1 に示した。より厳し いリフロー条件にするために，トップ温度を $260^{\circ} \mathrm{C} に$ 設定し

表 1 各種めっき皮膜の膜厚測定結果

\begin{tabular}{cccccc}
\hline & \multicolumn{3}{c}{ Pd-P } & \multicolumn{2}{c}{ Pure-P } \\
\hline $\mathrm{Ni}-\mathrm{P}$ & $\mu \mathrm{m}$ & 6.0 & 6.0 & 6.0 & 6.0 \\
$\mathrm{Pd}$ & $\mu \mathrm{m}$ & 0.06 & 0.18 & 0.06 & 0.19 \\
$\mathrm{Au}$ & $\mu \mathrm{m}$ & 0.04 & 0.04 & 0.04 & 0.03 \\
\hline
\end{tabular}

表 2 ボールプルテスト条件

\begin{tabular}{lll}
\hline はんだボール & 千住金属 & $\mathrm{Sn}-3.0 \mathrm{Ag}-0.5 \mathrm{Cu} 0.06 \mathrm{~mm} \phi$ \\
フラックス & 千住金属 & $529 \mathrm{D}-1 \mathrm{RMA}$ type \\
リフロー機 & TAMUEA & TMR-15-22 LH \\
リフロー条件 & Top 温度 $260^{\circ} \mathrm{C}$ & 5 回リフロー \\
ボールプル & Dage & シリーズ 4000 \\
プル速度 & $1000 \mu \mathrm{m} / \mathrm{sec}$ & \\
\hline
\end{tabular}


た。さらにマルチリフローを想定して, 計 5 回のリフローを 行い，はんだ接合評価を行った。結果，パラジウム膜厚が約 $0.2 \mu \mathrm{m}$ では両者ともに良好な結果は得られず，より薄い $0.06 \mu \mathrm{m}$ の膜厚において良好な結果を得た。さらに, 純パラ
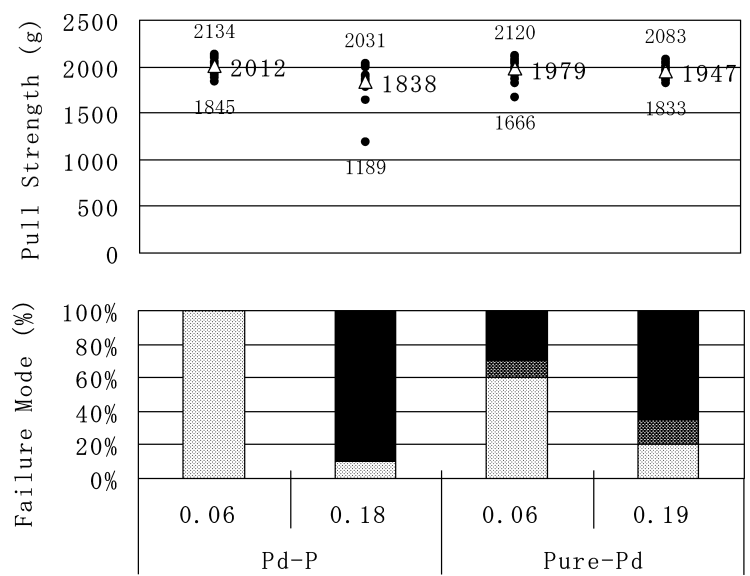

Pd thickness $(\mu \mathrm{m})$ A : Solder
D : Ni appear (most all)

B : Ni appear $(<25 \%$ area $)$

図 1 ボールプルテスト結果
ジウムよりもパラジウムーリン皮膜の方がより破壊モードが 良好であった。

\section{5.はんだ接合の長期信頼性テスト}

最も良好な結果が得られたパラジウムーリン皮膜 $0.06 \mu \mathrm{m}$ に対して, リフロー後に $150^{\circ} \mathrm{C} て ゙ 1000$ 時間までの長期信頼 性試験を行った。比較として従来の無電解 $\mathrm{Ni} / \mathrm{Au}$ めっき, $\mathrm{Ni}-\mathrm{P} / \mathrm{Au}=6.0 / 0.04 \mu \mathrm{m}$ も同時に評価した。

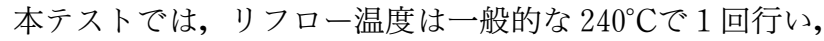

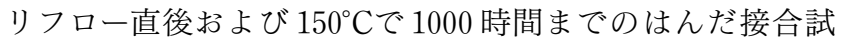
験を行った。また, 従来の $\mathrm{Sn}-37 \mathrm{~Pb}$ はんだでの接合試験もあ わせて行った。ボールプルテストは, 表 2 と同条件で行った。

図 2 の結果より, Sn-3.0 Ag-0.5 Cu はんだでは $\mathrm{Ni} / \mathrm{Pd} / \mathrm{Au}$

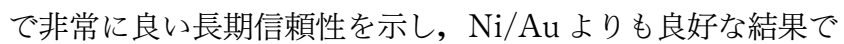
あった。しかし, $\mathrm{Sn}-37 \mathrm{~Pb}$ はんだでは $\mathrm{Ni} / \mathrm{Au}$ は良好な結果 であるが， $\mathrm{Ni} / \mathrm{Pd} / \mathrm{Au}$ は強度，破壊モードともに低下した。

一般的にはんだ接合の破壊モードは合金層(以降 IMC と 称す)の形成に問題があると考えられるため, この結果に対 応する IMC 界面の SEM 観察を行った。図 3 に示すように $\mathrm{Ni} / \mathrm{Pd} / \mathrm{Au}$ の IMC 形状変化は, はんだ材料に大きく依存し,
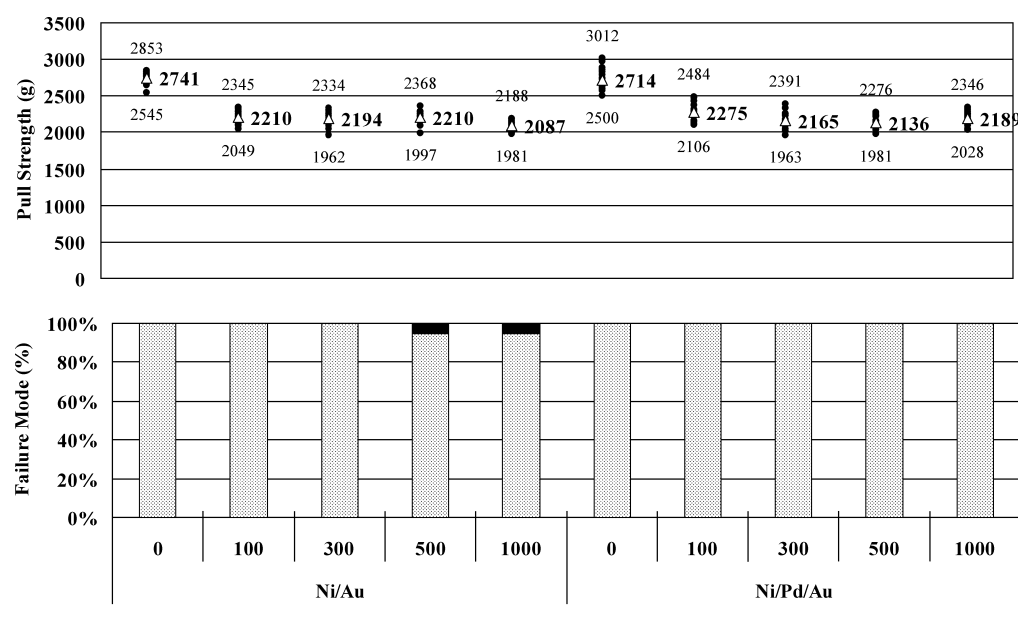

Sn-3.0Ag-0.5Cu はんだ

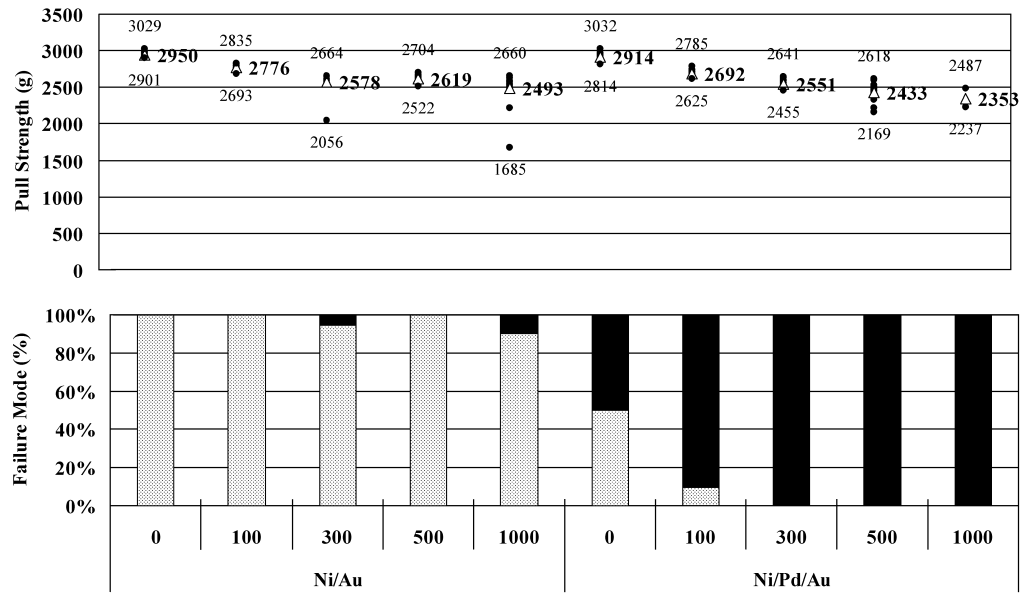

$\square \mathrm{A}$ : Solder Shear 圆 B : Inter metallic (Less than $25 \%$ area) $\square \mathrm{D}$ : Inter metallic (More than $25 \%$ area)

$\mathrm{Sn}-37 \mathrm{~Pb}$ はんだ

図 2 はんだ実装後に $150^{\circ} \mathrm{C}$ 条件下で放置 
Sn-3.0 Ag-0.5 Cu はんだを使用すると長期間にわたり IMC 形状の変化が少なく安定していることが確認できた。一方, Sn-37 Pb はんだでは IMC 形状が大きく変化することが確認 できた。

図 3 に示した IMC 形状変化と図 2 に示したソルダーボー ルプル特性の結果から, IMC 形状変化が大きい場合にはん だ接合性は低下し, IMC 形状変化の少ない条件では接合特 性も安定していることが推察される。

図 4 に $\mathrm{Ni} / \mathrm{Pd} / \mathrm{Au}$ に $\mathrm{Sn}-3.0 \mathrm{Ag}-0.5 \mathrm{Cu}$ と $\mathrm{Sn}-37 \mathrm{~Pb}$ はん だを実装して $150^{\circ} \mathrm{C}-1000$ 時間熱処理した後の接合界面での 各元素の分布を EPMA 法で比較した。図 4 が示すように Sn-3.0 Ag-0.5 Cu はんだでは $\mathrm{Ni}, \mathrm{Cu}, \mathrm{Pd}$ が接合界面に比 較的均一に存在し, $\mathrm{Ni}$ のはんだへの拡散が少ないことがわ かる。一方, $\mathrm{Sn}-37 \mathrm{~Pb}$ はんだでは $\mathrm{Pb}$ と $\mathrm{Pd}$ が分離凝縮し $\mathrm{Pb}$ が存在する場所での $\mathrm{Ni}$ 拡散は比較的遅いが $\mathrm{Pb}$ が存在し ていない場所での $\mathrm{Ni}$ 拡散が比較的早いことがわかった。こ れらより $\eta^{-}(\mathrm{Cu}, \mathrm{Ni})_{6} \mathrm{Sn}_{5}$ の IMC 層 ${ }^{1), 7)}$ および $\mathrm{Pb}$ がはんだ への $\mathrm{Ni}$ 拡散を抑える働きをしていると考えられる。すなわ ち $\mathrm{Ni} / \mathrm{Au}$ や $\mathrm{Ni} / \mathrm{Pd} / \mathrm{Au}$ のように $\mathrm{Sn}$ と無電解ニッケル皮膜 が IMC を作る場合，はんだ接合性はニッケルのはんだへの 拡散速度に大きく依存していることが推察できる。

\section{6. ワイヤーボンディング性}

従来の純パラジウム皮膜ではワイヤーボンディング性が良 いことは周知のとおりである。はんだ接合性を考慮すると従 来よりも膜厚を薄くする必要があるのでこの時のワイヤーボ ンディング性に与える影響を確認した。ワイヤーボンディン グテスト前の熱処理はおこなっていない。

表 1 の皮膜を用いてワイヤーボンディングテストを行った。 破壊モードは図 5 のとおり評価した。結果, 図 6 に示したと おり, 純パラジウムとパラジウムーリンで差はなく, 0.06 $\mu \mathrm{m}$ という薄い膜厚でも良好なワイヤーボンディング性が得 られることがわかった。

\section{7.まとめ}

本報では $\mathrm{Ni} / \mathrm{Pd} / \mathrm{Au}$ のはんだ接合性を調べ, $\mathrm{Pb}$ フリーは んだの接合性に関して, 従来よりも薄い $0.06 \mu \mathrm{m}$ 程度の膜 厚で良好な結果が得らることを示した。さらに純パラジウム とパラジウムーリン皮膜を比較すると後者の方が良好であっ た。一方 $\mathrm{Sn}-37 \mathrm{~Pb}$ はんだでは, $\mathrm{Ni} / \mathrm{Pd} / \mathrm{Au}$ は Ni/Auより も接合性は低下した。 $\mathrm{Ni} / \mathrm{Au}$ と $\mathrm{Ni} / \mathrm{Pd} / \mathrm{Au}$ および $\mathrm{Sn}-3.0$ $\mathrm{Ag}-0.5 \mathrm{Cu}$ と $\mathrm{Sn}-37 \mathrm{~Pb}$ の組み合わせで, はんだへの $\mathrm{Ni} の$

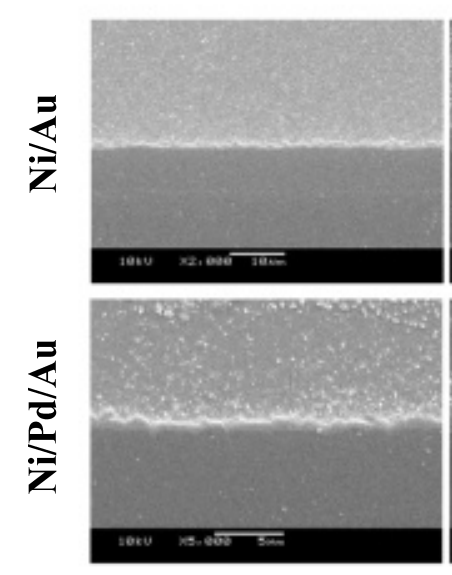

O hr
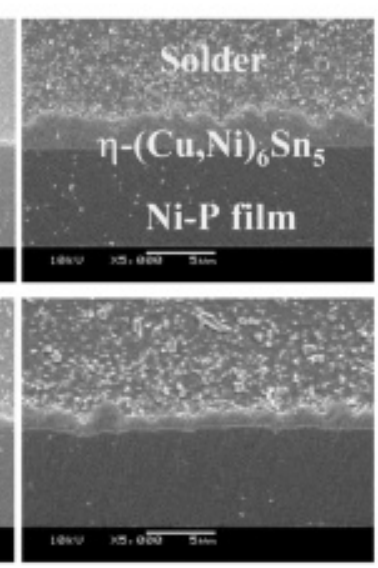

$1,000 \mathrm{hr}$

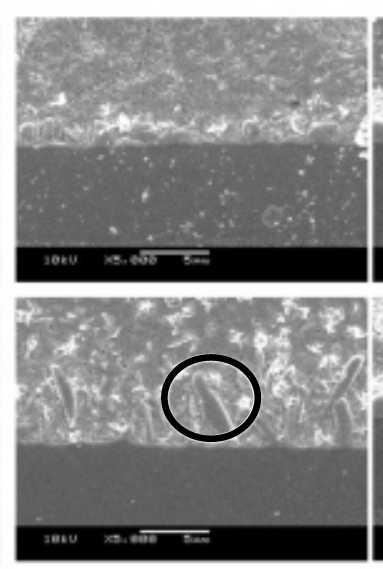

O hr
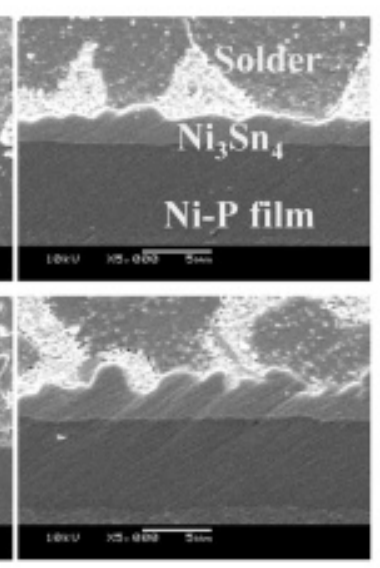

$1,000 \mathrm{hr}$

Sn-3.0Ag-0.5Cu はんだ

Sn-37Pb はんだ

図 3 はんだ実装後に $150^{\circ} \mathrm{C}$ 条件下での IMC 形状の経時変化

Sn-3.0Ag-0.5Cu はんだ

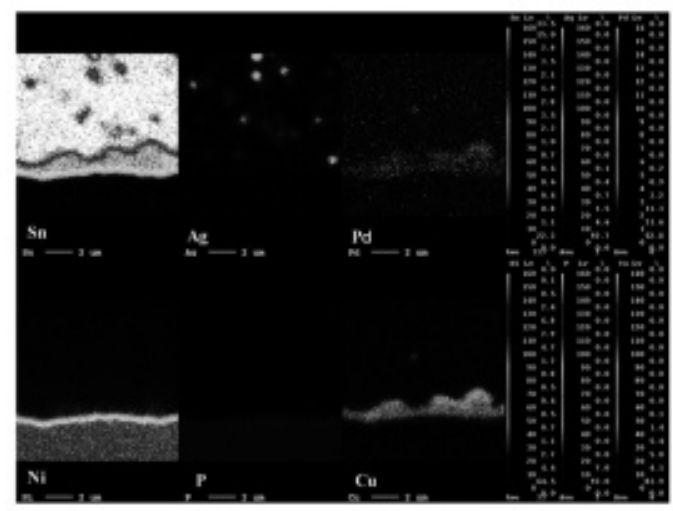

Sn-37Pb はんだ

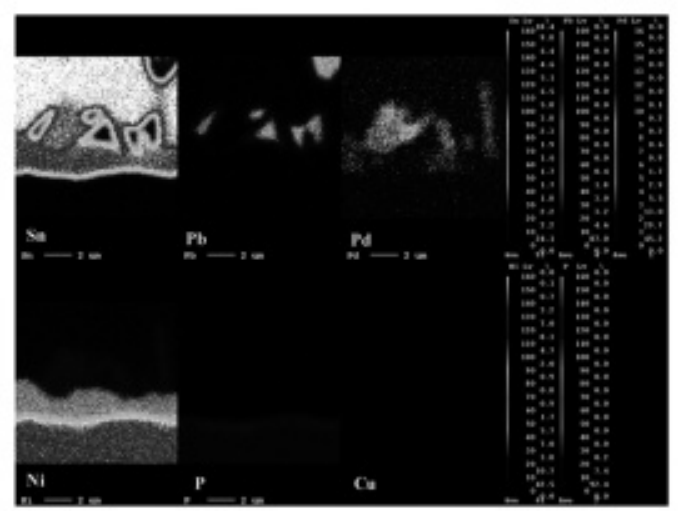

図 $4 \mathrm{Ni} / \mathrm{Pd} / \mathrm{Au}$ 皮膜にはんだボールを実装後, $150^{\circ} \mathrm{C}-1000$ 時間熱処理後の接合界面での各元素の分布 


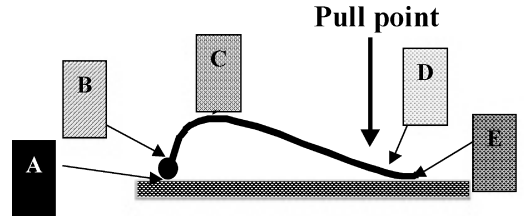

図 5 ワイヤープル評価モード
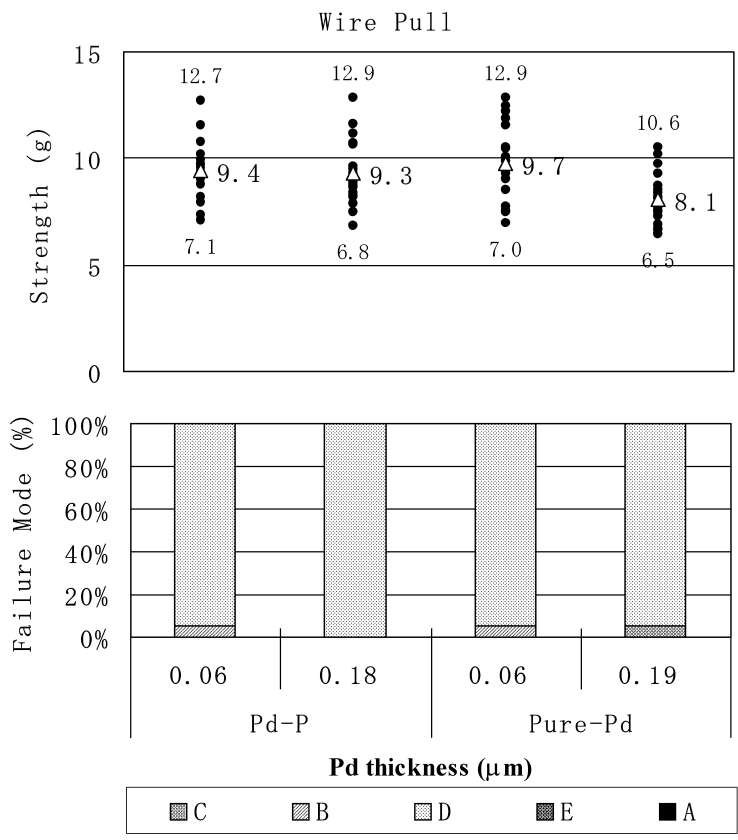

図 6 ワイヤープルテスト結果

拡散とはんだ接合性について検討を行った結果，Ni のはん だへの拡散を防止している組成因子として $\eta^{-}(\mathrm{Cu} ， \mathrm{Ni}) 。$ $\mathrm{Sn}_{5}$ と $\mathrm{Pb}$ であることを示した。 $\mathrm{Ni} / \mathrm{Pd} / \mathrm{Au}$ 皮膜に $\mathrm{Sn}-37 \mathrm{~Pb}$ はんだを実装した場合，Pd と $\mathrm{Pb}$ が分離凝縮することによ り $\mathrm{Ni}$ 拡散防止の働きがある $\mathrm{Pb}$ が存在しない部分が生じる ことで，過度の $\mathrm{Ni}$ 拡散が進みはんだ接合信頼性が劣化する と考察した。

\begin{tabular}{llr}
\hline ワイヤー & 1 mil-Gold & \\
キャピラリー & B 1014-51-18-12(PECO) \\
ワイヤーボンダー & TPT HB 16 & \\
ステージ温度 & $150^{\circ} \mathrm{C}$ & \\
Ultra sonic & $250 \mathrm{~mW}(1 \mathrm{st})$ & $250 \mathrm{~mW}(2 \mathrm{nd})$ \\
Bonding time & $200 \mathrm{msec}(1 \mathrm{st})$ & $50 \mathrm{msec}(2 \mathrm{nd})$ \\
Loading force & $25 \mathrm{~g}(1 \mathrm{st})$ & $50 \mathrm{~g}(2 \mathrm{nd})$ \\
Step & $0.7 \mathrm{~mm}(1 \mathrm{st}$ to $2 \mathrm{nd}$ wire length $)$ \\
ワイヤープル & Dage & シリーズ 4000 \\
プル速度 & $170 \mu \mathrm{m} / \mathrm{sec}$ & \\
\hline
\end{tabular}

また，ワイヤーボンディング性においては純パラジウム皮 膜と, パラジウムーりん皮膜で基本的な差がないことが確認 できた。

環境問題からはんだ材料が $\mathrm{Sn}-37 \mathrm{~Pb}$ はんだから $\mathrm{Sn}-3.0$ $\mathrm{Ag}-0.5 \mathrm{Cu}$ に急速に変更されている。 $\mathrm{Ni} / \mathrm{Pd} / \mathrm{Au}$ 処理はは んだ材料を $\mathrm{Sn}-\mathrm{Ag}-\mathrm{Cu}$ に限定して使用することが可能であ れば，Pd膜厚を $0.1 \mu \mathrm{m}$ 以下にすることで，はんだ接合性 とワイヤーボンディング性を高次元で両立させる可能性を有 している。

(2006-12-5 受理)

\section{文献}

1) Chi-Won Hwang and K. Suganuma: J. Mater. Res., 18, 2540, Nov (2003).

2 ) 森本啓仁, 辻本雅宣, 家治友美, 村上 透; 特開平 6-330336 号.

3 ) 縄舟秀美, 中尾誠一郎, 水本省三, 内田 衛, 岡田 隆; 表面技 術, 48, 474 (1997).

4 ) 内田 衛, 岡田 隆, 縄舟秀美, 中尾誠一郎, 水本省三 ; 表面技 術, 50, 469 (1999).

5 ）水本省三, 縄舟秀美, 内田 衛, 芳賀正記 ; 表面技術, 40，477 (1989).

6 ）渡辺秀人；表面技術, 55, 651 (2004).

7 ) 小田幸典, 木曽雅之, 橋本滋雄 ; UYEMURA TECHNICAL REPORTS, 59, 11, (2006). 